\title{
Collagen Hydrolysate Against Fluvoxamine Maleate- Induced Osteoporosis in Albino Rats: A Histological and Immunohistochemical Study \\ Original
} Article

\author{
Seham Abd Elhamid Mohamed Elkalawy', Maha Mohamed Abo Gazia ${ }^{2}$, Sally \\ Ahmed Abd Elaziz, Elekhtiar ${ }^{2}$ and Dalia Ibrahim Ismail ${ }^{1}$
}

Histology Department, Faculty of Medicine, ${ }^{1}$ Cairo University, ${ }^{2}$ Kafrelsheikh University, Egypt

\begin{abstract}
Background: Osteoporosis (OP) is a prevalent degenerative bone disease among patients receiving selective serotonin reuptake inhibitors as fluvoxamine maleate $(\mathrm{FM})$. Collagen hydrolysate $(\mathrm{CH})$ is a nutritional component that has antiresorptive effect.

Aim of Work: Evaluate the possible protective effect of $\mathrm{CH}$ against FM-induced OP in adult male albino rats.

Material and Methods: Thirty six rats were divided into 4 groups; group I (control), group II (OP group): injected with FM daily for 4 weeks, group III (CH group): received FM concomitant with oral $\mathrm{CH}$ for 4 weeks, group IV (recovery group]: received only FM for 4 weeks \& were left without taking any drugs for another 4 weeks. Total serum alkaline phosphatase (ALP) and calcium $\left(\mathrm{ca}^{+2}\right)$ were measured. Bone specimens from the right femurs and first lumbar vertebrae were processed for H\&E stain, Mallory's trichrome stain and immunohistochemical staining for osteopontin (OPN) and proliferating cell nuclear antigen (PCNA). This was followed by morphometric \& statistical analysis.

Results: Both groups II \& IV showed significant elevation in ALP \& reduction in $\mathrm{Ca}^{+2}$ compared to control. Bone sections revealed evident histological changes; osteocytes with pyknotic nuclei inside widened lacuna, widened haversian canals. Bone matrix showed fain areas, cavitations \& multiple resorption cavities with osteoclasts. There was significant reduction in the mean thickness of compact bone, the mean area of trabecular bone, area \% of OPN \& mean number of PCNA +ve cells compared to control. Group III exhibited significant reduction in ALP \& elevation in $\mathrm{Ca}^{+2}$. The bone showed preserved histological architecture almost as the control. There was significant increase in the mean thickness of compact bone, the mean area of trabecular bone, area $\%$ of OPN \& mean number of PCNA +ve cells compared to groups II \& IV.

Conclusion: $\mathrm{CH}$ has a potential osteoprotective effect against FM-induced osteoporosis.
\end{abstract}

Received: 25 January 2020, Accepted: 02 March 2020

Key Words: Collagen hydrolysate; fluvoxamine maleate; Osteoporosis; Osteopontin; PCNA.

Corresponding Author: Dalia Ibrahim Ismail, MD, Department of Histology, Faculty of Medicine, Cairo University, Cairo, Egypt, Tel.: +20 1005050870, E-mail: drdaliaibrahim@hotmail.com

ISSN: 1110-0559, Vol. 43, No.4

\section{INTRODUCTION}

Osteoporosis (OP) is a globally growing health problem affecting over 200 million people worldwide and the annual incidence of hip fracture due to this disease is about 1.7 million worldwide ${ }^{[1]}$. It is characterized by deterioration of bone tissue and low bone mass because of enhanced bone resorption that is not compensated by enhanced bone formation, increasing fracture risk ${ }^{[2]}$. Primary OP is associated with aging and is more common in women especially postmenopausal due to decreased estrogen. Secondary OP occurs as a result of medical conditions as rheumatoid arthritis, kidney failure, Cushing syndrome, hormonal causes as diabetes and hyperparathyroidism, or due to long-term usage of anticonvulsant, corticosteroid, antidepressant and antipsychotic drugs ${ }^{[1,3]}$.

The prevalence of OP has been increased among patients with depression due to treatment with antidepressants especially selective serotonin reuptake inhibitors (SSRIs) ${ }^{[4]}$, which are frequently used due to better patient's compatibility and less anticholinergic adverse effects ${ }^{[5]}$, nevertheless, they have been found to exert negative effects on bone density and increase fracture risk within the first eight months ${ }^{[6,7,8]}$. Serotonin 5-hydroxytryptamine (5-HT) receptors have been recognized on osteoblasts, osteocytes and osteoclasts, and the effect of SSRIs on bone appears to be controlled by the activation of these receptors via autocrine, paracrine, endocrine and neuronal pathways; so SSRIs are considered as a secondary cause of $\mathrm{OP}^{[9]}$.

Fluvoxamine (FM) is an effective specific SSRI available since 1983. It binds to serotonin transporter selectively, blocking serotonin reuptake into the pre-synaptic neurons; thus enhancing the serotonergic outcome in the brain ${ }^{[10]}$. It is recommended as a first line therapy for a number of psychotic disorders as depression that is a common major disorder affecting $20 \%$ of the individuals within their lifetime ${ }^{[11]}$, delirium $^{[12]}$, anxiety disorders which are the most prevalent 
psychiatric disorders and women are twice as commonly affected as $\operatorname{men}^{[13]}$, obsessive-compulsive disorder which is the fourth most common mental disorder ${ }^{[14]}$, traumatic brain injury that is extensively followed by disorders of mood, attention, sleep and anxiety ${ }^{[15]}$.

Current treatments for OP are dominated by drugs that suppress bone formation and may contribute to the pathogenesis of osteonecrosis. To restore the extensive bone loss, there is a great need for anabolic treatments that induce osteoblasts to build new bone ${ }^{[16]}$.

Collagen type I is the main structural protein dispersed throughout the body; forming $25 \%$ of the total body protein and $80 \%$ of the total connective tissue in humans. Also, it is an important bone component; being the main extracellular matrix protein and plays a role in osteoblast differentiation as well ${ }^{[17]}$. Nowadays; researches are directed at naturally occurring agents that possess a potential antiresorptive effect and collagen hydrolysate $(\mathrm{CH})$, hydrolyzed collagen type $\mathrm{I}$, is one of these agents currently under analysis. It results from partial hydrolysis of gelatins (bovine, pocrine or fish) to enhance their solubility and absorption ${ }^{[18]}$. $\mathrm{CH}$ consists of small peptides with low molecular weight (collagen peptides, $\mathrm{CP}$ ) enriched in specific amino acids: proline, hydroxyproline and glycine ${ }^{[19]}$. $\mathrm{CH}$ has been receiving attention as a probable oral supplement for the recovery of osteoarticular tissue ${ }^{[20]}$; as it has a better outcome on bone health when administered orally in combination with calcium and vitamin $\mathrm{D}^{[21]}$.

Osteopontin(OPN), a highly phosphorylated sialoprotein, is a major constituent of mineralized extracellular matrices of teeth and bones. It plays a significant role in the attachment and mineralization of osteoblasts; so it marks mature osteoblasts and the beginning of their bone mineralization activity and also indicates osteoblastic differentiation ${ }^{[22,23,24]}$. Proliferating Cell Nuclear Antigen (PCNA) is an auxiliary protein of DNA-polymerase enzymes, essential for DNA synthesis and is used as a marker for proliferating cells ${ }^{[25]}$.

Although many studies have addressed the effect of collagen peptides in osteoporotic models, there is no experimental or clinical data concerning its role when accompanied with SSRIs therapy especially FM (the most commonly used one), and whether this combination will protect the bone tissue or not. Moreover, no studies were done on the affection of trabecular bone following FM administration. Accordingly, the aim of the present work was to examine if consuming $\mathrm{CH}$ concomitantly with fluvoxamine maleate could protect the bone (both compact and spongy) against OP. This was done in adult male albino rat using laboratory, histological, immunohistochemical and statistical methods.

\section{MATERIALS AND METHODS}

Materials

Drugs

- $\quad$ Fluvoxamine maleate (FM), with trade name Faverin (Pharco Pharmaceuticals, Alexandria, Egypt), was supplied in the form of tablets $50 \mathrm{mg}$ each and was dissolved in $50 \mathrm{~mL}$ normal saline $(0.9 \% \mathrm{Nacl})$; so that each rat receives $0.4 \mathrm{~mL}$ saline containing $0.4 \mathrm{mg}$ FM.

- Collagen hydrolysate $(\mathrm{CH})$ (Great Lakes Gelatin Company, Illinois, USA), was supplied in the form of sachets each contains $12 \mathrm{~g} \mathrm{CH}$ powder that was dissolved in $12 \mathrm{~mL}$ distilled water; so that each rat receives $0.5 \mathrm{~mL}$ distilled water containing $0.5 \mathrm{~g}$ $\mathrm{CH}$.

\section{Animals}

This study included 36 adult male albino rats about 3 months old and with average weight (180- 200 grams). They were housed in the Animal House of Kasr Al-Ainy Faculty of Medicine, Cairo University. They were kept in stainless steel cages under standard environmental conditions with free access to standard diet and water throughout the experimental period. All the experimental procedures were done according to guidelines approved by the Animal Use Committee of Cairo University.

\section{Experimental design}

\section{Rats were divided into 4 groups}

- Group I: Control group included 9 rats that were subdivided equally into:

- Subgroup IA: rats were injected with $0.4 \mathrm{~mL}$ normal saline subcutaneously (SC) daily for 4 weeks (corresponds to group II).

- Subgroup IB: rats were injected with $0.4 \mathrm{~mL}$ normal saline $\mathrm{SC}$ with concomitant oral administration of $0.5 \mathrm{~mL}$ distilled water via gastric gavage daily for 4 weeks (corresponds to group III).

- $\quad$ Subgroup IC: rats were injected with $0.4 \mathrm{~mL}$ saline SC daily for 4 weeks then stopped, and the rats were left without taking any injections for another 4 weeks (corresponds to group IV). 
- Group II: Osteoporosis group (OP group) included 9 rats that were injected SC with FM dissolved in normal saline in a dose of $2 \mathrm{mg} / \mathrm{kg} /$ day for 4 weeks ${ }^{[26]}$.

- Group III: Collagen hydrolysate group (CH group) included 9 rats that received FM as in group II concomitant with oral $\mathrm{CH}$ in a dose of $2.5 \mathrm{~g} / \mathrm{kg} /$ day for 4 weeks $^{[27]}$.

- Group IV: Recovery group included 9 rats that received FM as in group II for 4 weeks only and they were left without taking any drugs for another 4 weeks.

\section{Methods}

\section{Laboratory investigations}

At the end of experimental duration for each group and just before scarification, blood samples were taken from the tail veins in heparinized capillary tubes. They were analyzed for alkaline phosphatase (ALP) and calcium $\left(\mathrm{Ca}^{+2}\right)$ in Medical Biochemistry Department, Faculty of Medicine, Cairo University.

\section{Histological examination}

According to experimental duration, rats were sacrificed by intraperitoneal injection of phenobarbital $\left(80 \mathrm{mg} / \mathrm{kg}^{[28]}\right.$. Specimens from the upper end of the right femur just below the greater trochanter (compact bone) and from the first lumbar vertebra (trabecular bone) were dissected and excised, fixed in $10 \%$ buffered formalin solution for 24 hours, then were decalcified by the daily exchange of ethylene-diamine tetraacetic acid (EDTA) for 4 weeks ${ }^{[29]}$. After decalcification, specimens were dehydrated in ascending grades of ethanol $(70 \%, 95 \%$, and $100 \%)$, cleared in xylol and embedded in paraffin wax. Serial sections of 5-7 $\mu \mathrm{m}$ were cut using Leica rotator microtome (Germany) and were subjected to the following:

1. Hematoxylin \& eosin (H\&E) $\operatorname{stain}^{[30]}$.

2. Mallory's trichrome $\operatorname{stain}^{[31]}$ for detection of mineralized (mature) collagen fibers.

3. Immunohistochemical $\operatorname{stain}^{[31]}$ using:

- Anti osteopontin antibody (OPN): a ready to use mouse monoclonal antibody (Lab Vision Corporation, CA, USA, catalogue number SAB4200018). Positive cells showed brown cytoplasmic reaction

- Anti Proliferating Cell Nuclear Antigen antibody (PCNA): a ready to use mouse monoclonal antibody (Lab Vision Corporation, CA, USA, catalogue number MS106P). Positive cells show brown nuclear deposits.
Sections were counter stained with hematoxylin stain and the negative control sections were prepared by omitting the primary antibody.

\section{Morphometric study}

This was done using "Leica Qwin 500" software image analyzer computer system (Leica image system Ltd; Cambridge, England). In 10 non-overlapping randomly chosen fields for each section and using an objective lens of x10 magnification, the following parameters were measured:

1. Thickness of compact bone in H\&E stained sections.

2. Area of trabecular bone in H\&E stained sections.

3. Area percent of collagen fiber content in Mallory's trichrome-stained sections.

4. Area percent of osteopontin immunoreaction.

5. Number of PCNA immunoreactive osteoblasts.

\section{Statistical Analysis}

Laboratory and morphometric results were statistically analyzed using SPSS package version 21 (SPSS Inc., Chicago, USA). Comparisons between groups were done using ANOVA (analysis of variance) followed by post hoc Tukey test. Data were expressed as mean and standard deviation (SD) for the quantitative variable. Results were considered significant when $p<0.05^{[32]}$.

\section{RESULTS}

\section{Laboratory results}

Laboratory investigation results are illustrated in (Table 1)

\section{Histological Results}

\section{Hematoxylin and Eosin stained sections \\ Femur sections}

Transverse sections of femurs from the control rats (group I) showed regular bone lamellae with homogenous deep eosinophilic matrix and multiple distinct cement lines. Osteocytes inside their lacunae were seen in between these lamellae surrounding haversian canals and the endosteum revealed many osteoblasts (Figure 1a). Whereas sections from group II (OP group) displayed evident histological changes; the bone matrix showed faintly stained areas with multiple cavities and indistinct cement lines. Osteocytes were seen with small dark nuclei inside widened lacunae and around widened haversian canals. The endosteal surface was interrupted with no apparent osteoblasts and showed several resorption cavities with multiple large osteoclasts 
having eosinophilic cytoplasm and multiple nuclei (Figures 1b, 1c). Femur sections from group III (CH group) showed preservation in bone microstructure similar to the control; regular bone lamellae with multiple distinct cement lines, deep eosinophilic homogenous bone matrix, osteocytes inside their lacunae around haversian canals and multiple osteoblasts lining smooth endosteum (Figure 1d). Group IV (recovery group) showed no improvement; there were the same histological alterations seen in group II (Figures 1e, 1f).

\section{Lumbar vertebrae sections}

Transverse sections of lumbar vertebrae from the control group (group I) revealed multiple thick bone trabeculae enclosing bone marrow cavities that contained hematopoietic tissue, scattered adipocytes and blood sinusoids, and the bone matrix was homogenously eosinophilic. Osteocytes resided in their lacunae and the endosteal surfaces displayed multiple osteoblasts (Figure 2a). Regarding group II (OP group), there were thin interrupted bone trabeculae with wide marrow cavities filled with numerous fat cells. Few osteocytes were seen and the endosteal surfaces showed multiple resorption cavities with no apparent osteoblasts (Figure 2b). Group III (CH group) demonstrated trabecular bone almost preserving its normal histological architecture; thick branching and anastomosing trabeculae with homogenous eosinophilic matrix and highly cellular marrow cavities containing blood sinusoids. Multiple osteocytes were seen inside their lacunae and the endosteal surfaces were smooth and lined with multiple cuboidal osteoblasts (Figure 2c). Group IV (recovery group) showed the same histological changes as group II (Figure 2d)

\section{Mallory trichrome stained sections}

Transverse sections of femur and lumbar vertebrae from the control rats (group I) displayed bone formed mostly of mineralized bone matrix with very small areas of unmineralization and osteocytes were seen inside their lacunae (Figures 3a, 4a). As regards group II (OP group), bone sections exhibited unmineralized bone matrix in most areas with the presence of resorption cavities. There were small areas of mineralized bone matrix (Figures $3 b, 4 b$ ) Sections from group III ( $\mathrm{CH}$ group) revealed histological picture typical to the control (Figures 3c, 4c). Whereas group IV (recovery group) showed unmineralization in most areas of bone matrix with small mineralized areas (Figures 3d, 4d)

\section{Immunohistochemical results}

\section{OPN immunostained sections}

Femur and lumbar vertebrae sections of the control rats (group I) exhibited positive OPN immunoreaction that appeared as brown cytoplasmic deposits in osteoblasts lining the endosteum and in bone matrix (Figures 5a, 6a). Whilst group II (OP group) displayed negative OPN immunoreactivity within both the osteoblasts and bone matrix (Figures 5b, 6b). Sections from group III (CH group) showed brown positive OPN immunoreaction in the cytoplasm of osteoblasts and in bone matrix (Figures 5c, 5d). Regarding group IV (recovery group); there was negative OPN immunoreaction in both osteoblasts and bone matrix (Figures 6c, 6d).

\section{PCNA immunostained sections}

Control sections from femur and lumbar vertebrae (group I) revealed positive PCNA immunoreactivity, which appeared as brown nuclear deposits in the osteoblasts (Figures 7a, 8a). Concerning sections from group II (OP group); there was negative PCNA immunoreaction in the osteoblasts (Figures 7b, 8b). PCNA immunostained sections from group III ( $\mathrm{CH}$ group) presented brown nuclear PCNA immunoreactivity within the osteoblasts (Figures 7c, 8c). Whilst group IV (recovery group), showed osteoblasts with negative PCNA immunoreaction (Figures 7d, 8d).

\section{Morphometric results}

Morphometric results are illustrated in (Table 2). 

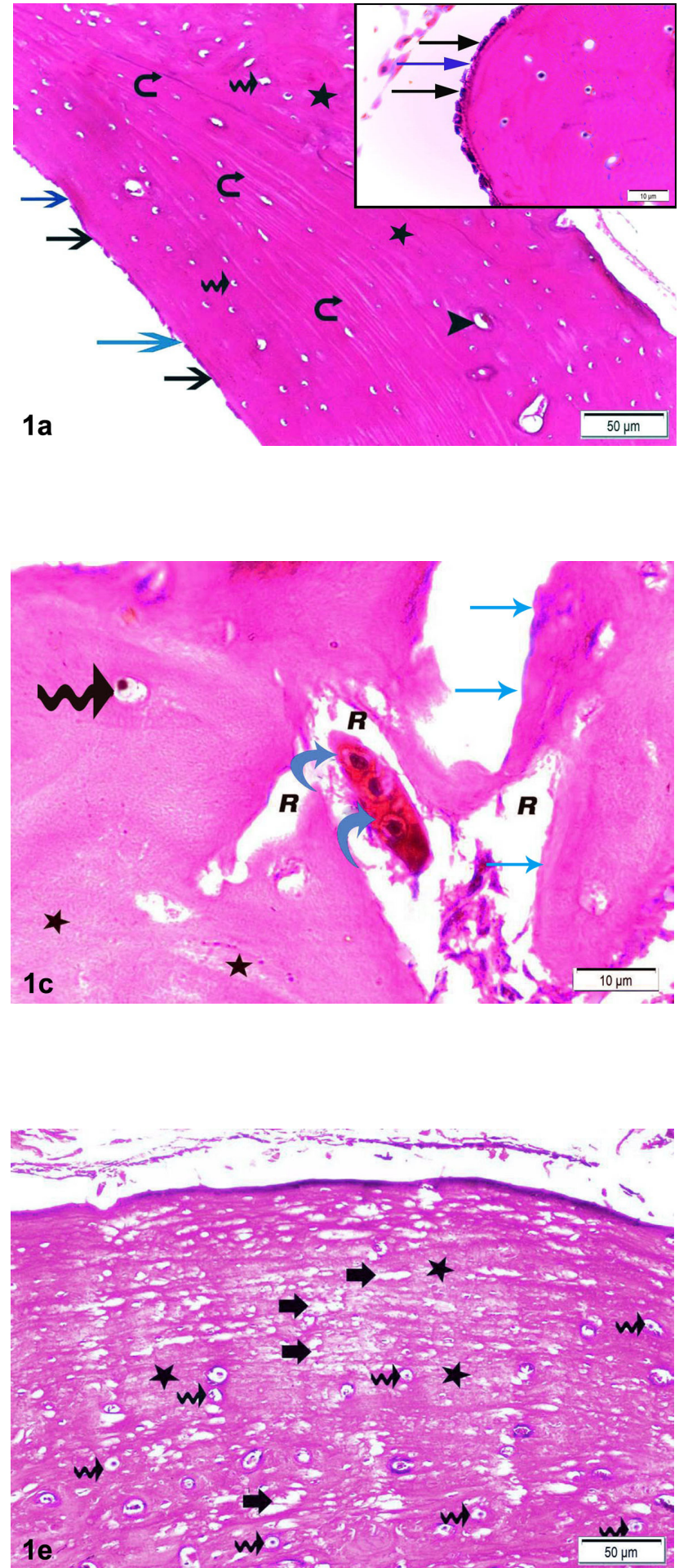
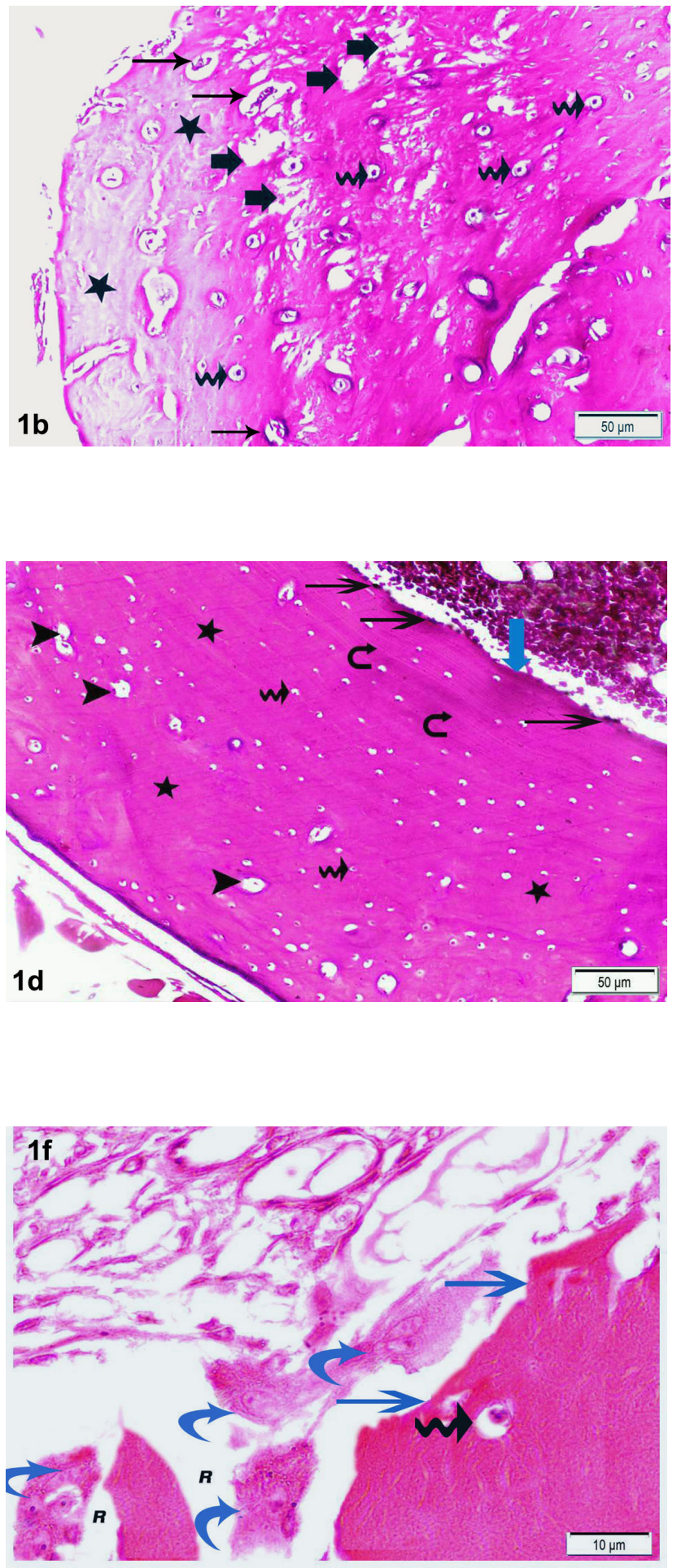

Fig. 1: Photomicrographs of transverse sections from rats' femurs stained with H\&E. 1a) Group I (control group) shows regular bone lamellae with homogenous deep eosinophilic matrix (black stars) and multiple distinct cement lines (curved arrow). Osteocytes are seen in their lacunae (wavy arrows) around haversian canals (arrowheads) and the endosteum (blue arrow) is lined with numerous osteoblasts (black arrow) (x200). The inset is a higher magnification of the endosteal surface (blue arrow) with multiple osteoblasts (black arrows) (x1000). 1b) Group II (OP group) displays multiple cavities (thick arrows) within faint bone matrix (black stars), widened osteocytes lacunae (wavy arrows) and haversian canals (thin arrows) (x200). 1c) Higher magnification shows an osteoclast (blue curved arrows) in a large resorption cavity (R) and the endosteal surface with no osteoblasts (blue arrows). The bone matrix exhibits faintly stained areas (black stars) and an osteocyte appears with small dark nucleus (wavy arrow) (x1000). 1d) Group III (CH group) presents regular bone lamellae with homogenous deep eosinophilic matrix (black stars) and multiple distinct cement lines (curved arrows). Osteocytes inside their lacunae (wavy arrows) surround haversian canals (arrowheads). The endosteum (blue arrow) is lined with multiple osteoblasts (black arrow) (x200). 1e) Group IV (recovery group) reveals faintly stained matrix (black stars), multiple cavities (thick arrows) and widened osteocytes lacunae (wavy arrows) (x200). 1f) Higher magnification shows multiple osteoclasts (blue curved arrows) within large resorption cavities (R). No osteoblasts lining the endosteum (blue arrows) and an osteocyte with a karyolytic nucleus is seen (wavy arrow) (x1000). 

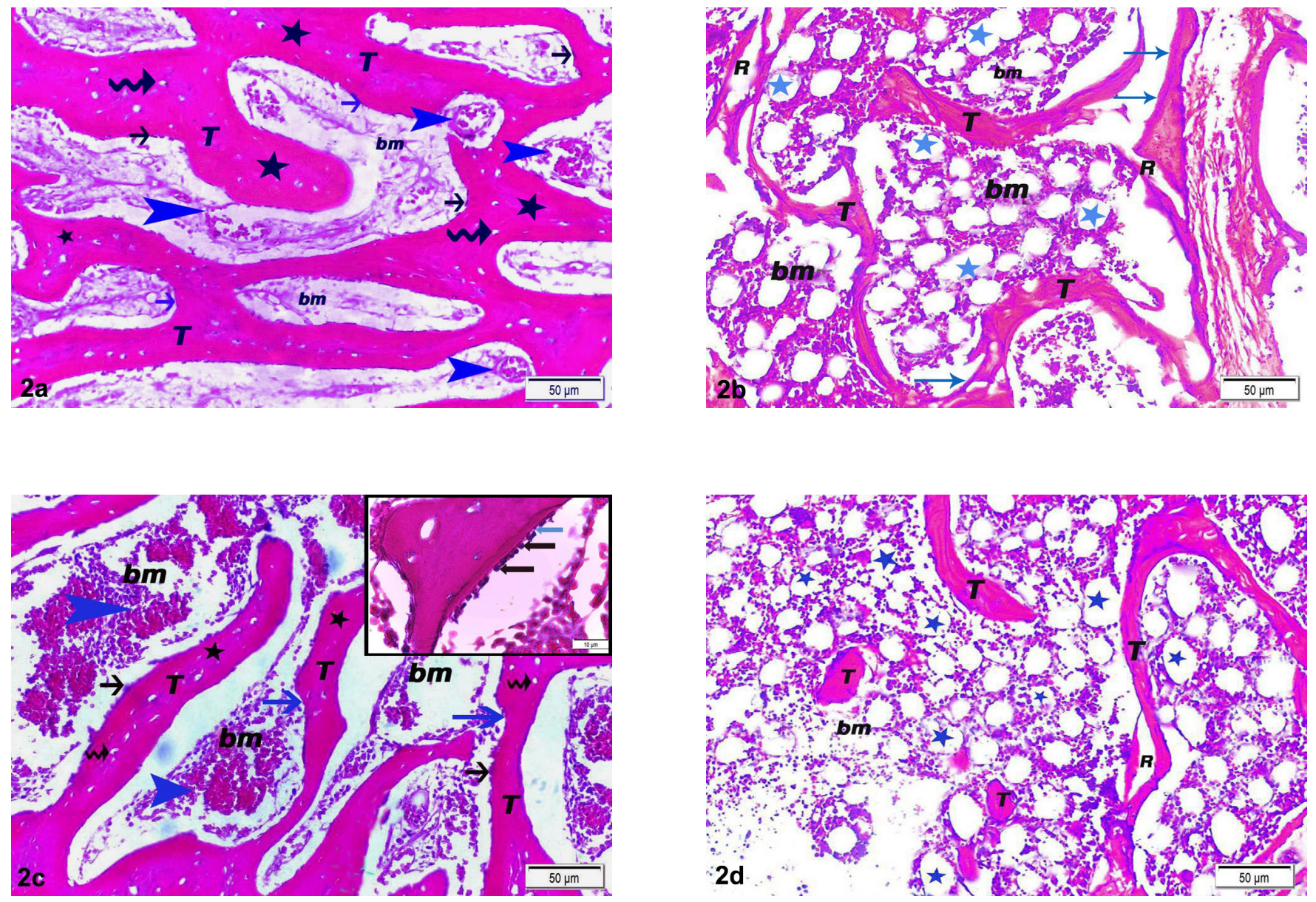

Fig. 2: Photomicrographs of transverse sections from rats' lumbar vertebrae stained with H\&E. 2a) Group I (control group) displays multiple thick bone trabeculae $(\mathrm{T})$ enclosing bone marrow cavities (bm) with many blood sinusoids (blue arrowheads). Osteocytes inside their lacunae (wavy arrow), homogenous eosinophilic bone matrix (black stars) and smooth endosteal surfaces (blue arrows) lined by osteoblasts (black arrows) are seen. (x200). 2b) group II (OP group) shows thinning of bone trabeculae (T) with resorption cavities (R), no osteoblasts lining the endosteum (blue arrows), and wide marrow cavities (bm) filled with numerous fat cells (blue stars) (x200). 2c) Group III (CH group) presents thick branching and anastomosing bone trabeculae (T) with homogenous eosinophilic matrix (black stars). They enclose highly cellular marrow cavities (bm) containing blood sinusoids (blue arrowheads). Osteocytes reside in their lacunae (wavy arrows) and the endosteal surface is smooth (blue arrows) and lined with osteoblasts (black arrows) (x200). The inset is a higher magnification for the smooth endosteal surface (blue arrow) lined with multiple cuboidal osteoblasts (black arrows) (x1000). 2d) Group IV (recovery group) shows thin interrupted bone trabeculae (T) with resorption cavity (R) and wide bone marrow cavities (bm) filled with numerous fat cells (blue stars) (x200). 

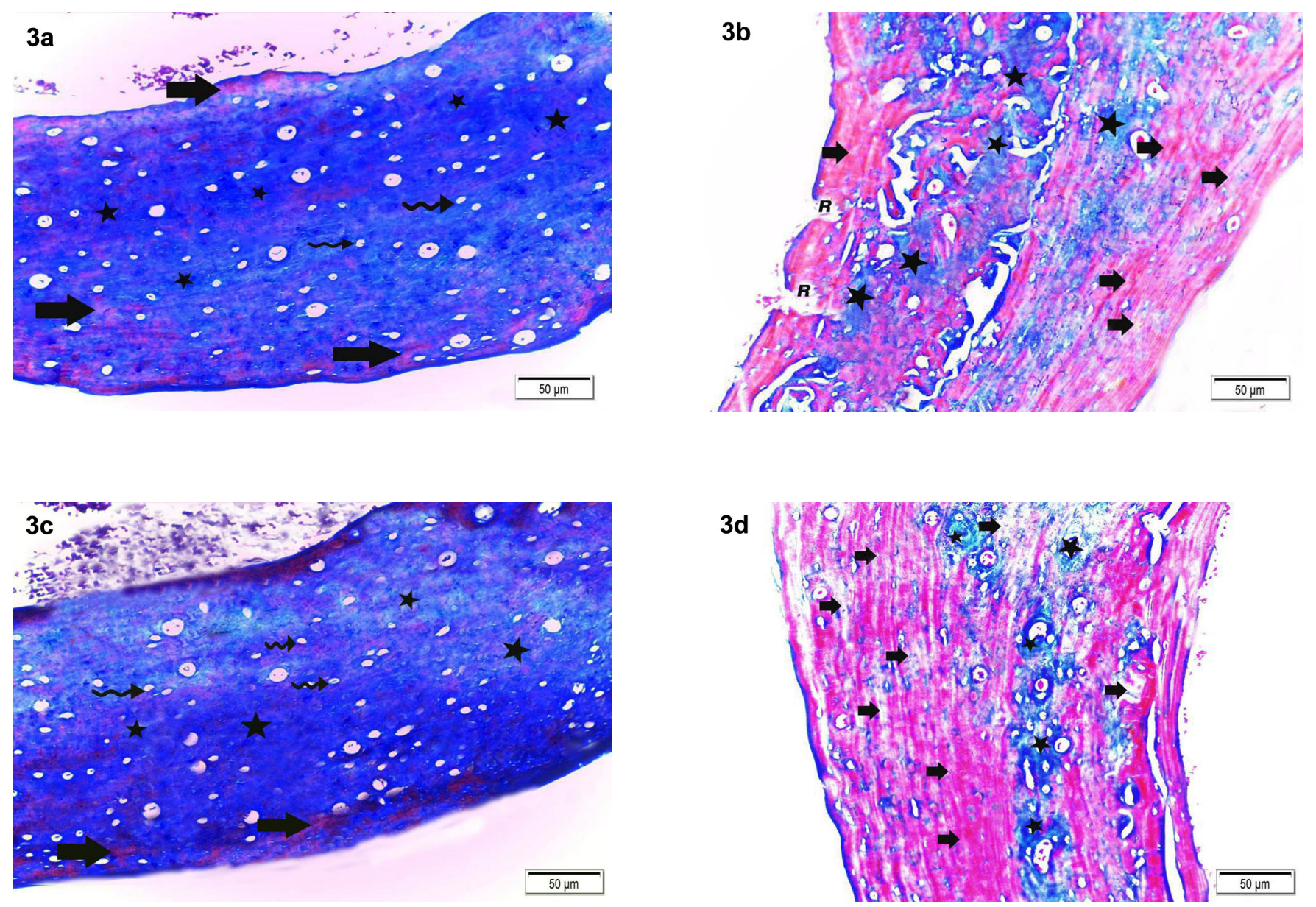

Fig. 3: Photomicrographs of transverse sections from rats' femurs stained with Mallory's trichrome stain x200. 3a) Group I (control group) reveals bone formed mostly of mineralized bone matrix (stars) with very small unmineralized areas (thick arrows). Osteocytes are seen inside their lacunae (wavy arrows). $3 \mathrm{~b}$ ) group II (OP group) shows mainly unmineralized bone matrix (thick arrows) with resorption cavities (R). There are small mineralized areas (stars). 3c) Group III (CH group) displays mostly mineralized bone matrix (stars) with osteocytes (wavy arrows) in between. Very small areas of unmineralization are seen (thick arrows). 3d) Group IV (recovery group) exhibits unmineralized bone matrix (thick arrows) with the presence of small areas of mineralization (stars). 

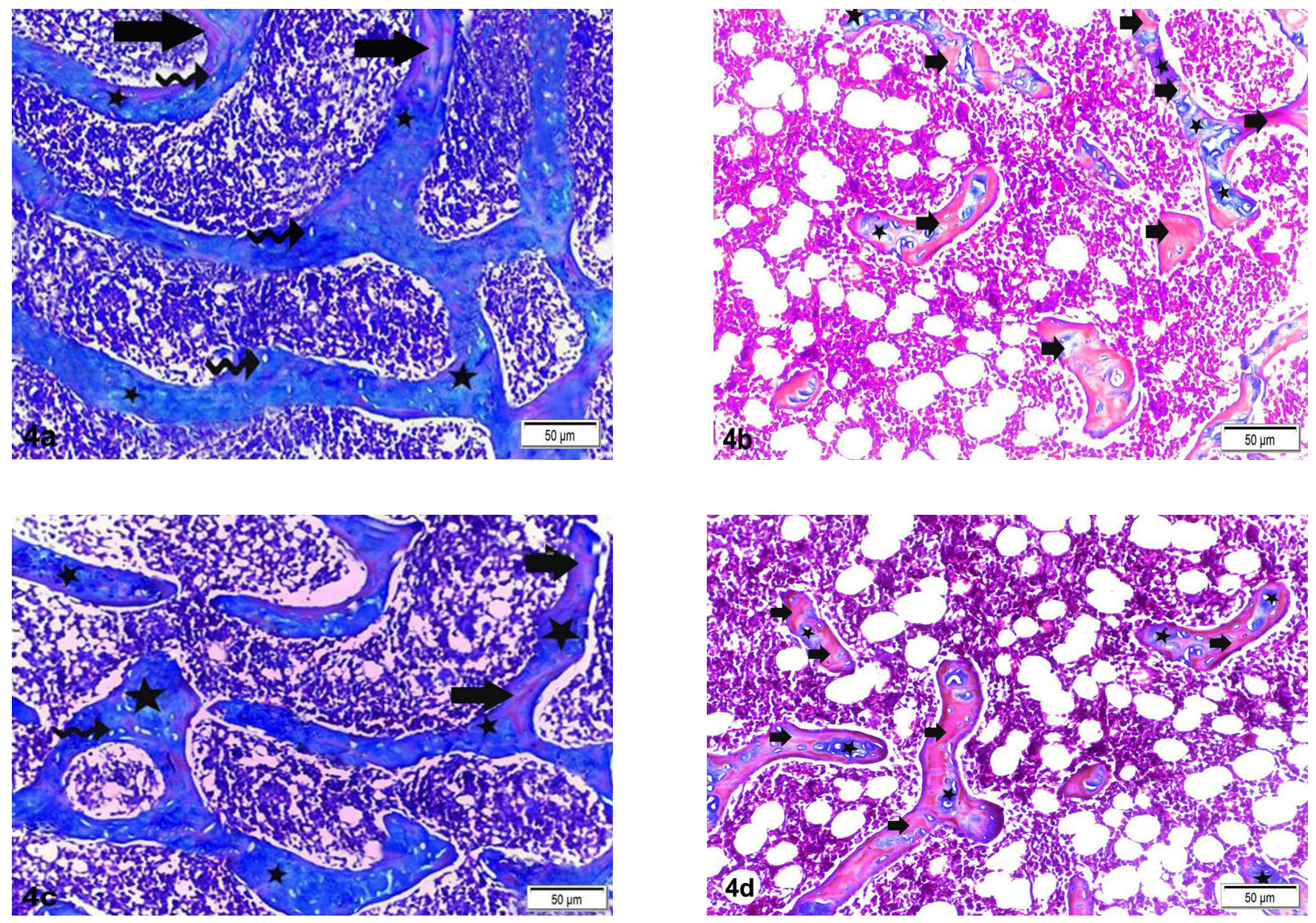

Fig. 4: Photomicrographs of transverse sections from rats' lumbar vertebrae stained with Mallory's trichrome stain x200. 4a) Group I (control group) shows branching and anastomosing bone trabeculae formed mostly of mineralized bone matrix (stars) with osteocytes in their lacunae (wavy arrows). Very small unmineralized areas (thick arrows) are seen. 4b) Group II (OP group) reveals mostly unmineralized bone matrix (thick arrows) with small areas of mineralization (stars). 4c) Group III (CH group) displays branching and anastomosing bone trabeculae formed mostly of mineralized matrix (stars) with osteocytes inside their lacunae (wavy arrows). There are small areas of unmineralization (thick arrows). 4d) Group IV (recovery group) shows mostly unmineralized matrix (thick arrows) with small areas of mineralization (stars). 

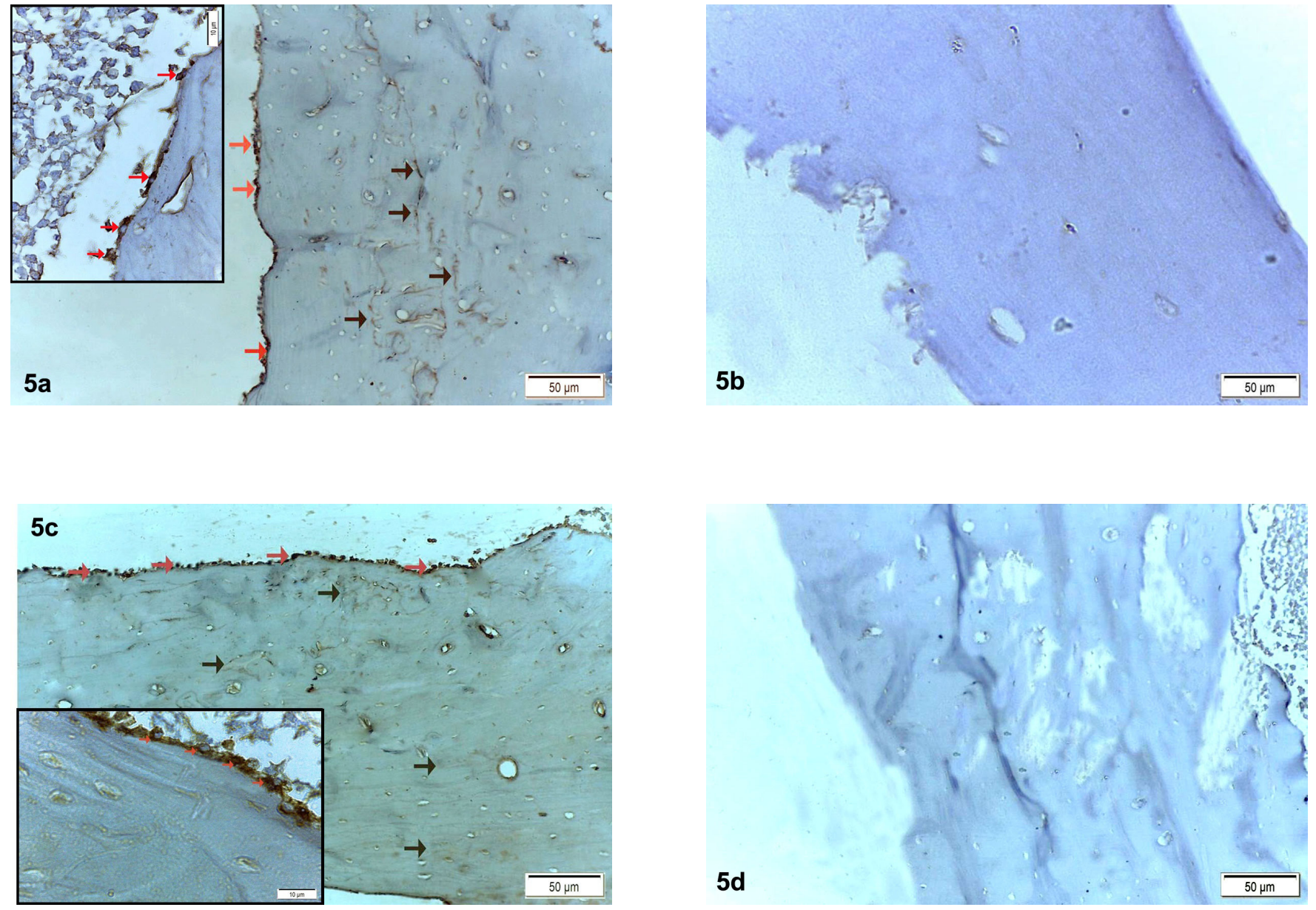

Fig. 5: Photomicrographs of transverse sections from rats' femurs immunostained with anti OPN antibody. 5a) Group I (control group) presents +ve OPN immunoreactivity within the osteoblasts (red arrow) and the bone matrix (black arrow) (x200). The inset is a higher magnification for $+\mathrm{ve}$ OPN immunoreactive osteoblasts with brown cytoplasmic deposits (red arrow) (x1000). 5b) Group II (OP group) shows -ve OPN immunostaining. 5c) Group III (CH group) reveals +ve OPN immunoreactivity within the cytoplasm of osteoblasts (red arrow) and in the bone matrix (black arrow) (x200). The inset is a higher magnification for +ve OPN immunoreactive osteoblasts (red arrows) (x1000). 5d) Group IV (recovery group) shows -ve OPN immunoreaction (x200). 

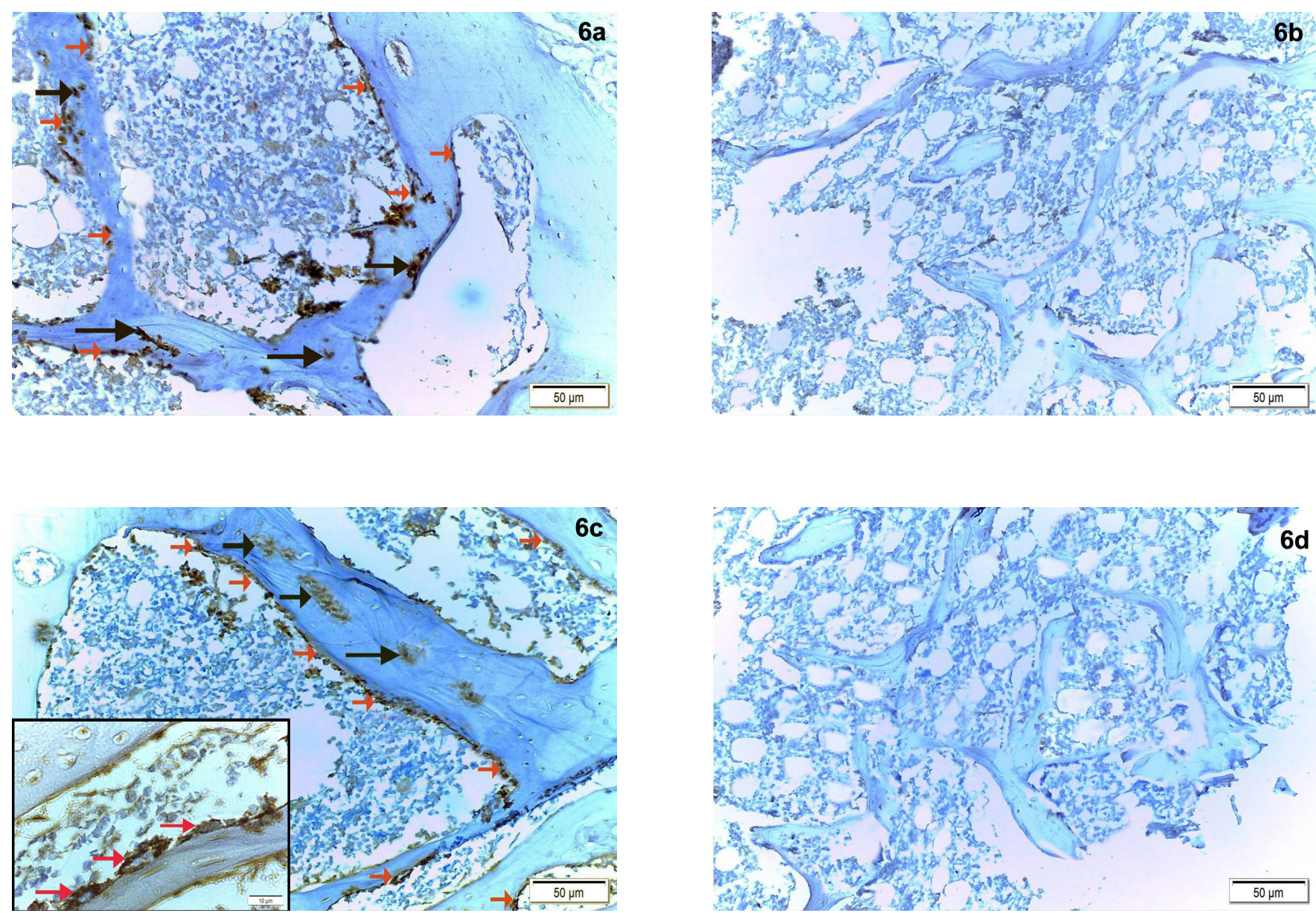

Fig. 6: Photomicrographs of transverse sections from rats' lumbar vertebrae immunostained with anti OPN antibody. 6a) Group I (control group) exhibits +ve OPN immunoreactivity appearing as brown cytoplasmic deposits in the osteoblasts (red arrow) and bone matrix (black arrow) (x200). 6b) Group II (OP group) shows -ve OPN immunoreaction (x200). 6c) Group III (CH group) displays +ve OPN immunostaining within the cytoplasm of osteoblasts (red arrow) and in the bone matrix (black arrow) (x200). The inset is a higher magnification showing osteoblasts with +ve OPN immunoreaction (red arrow) (x1000). 6d) Group IV (recovery group) shows -ve OPN immunoreaction (x200). 

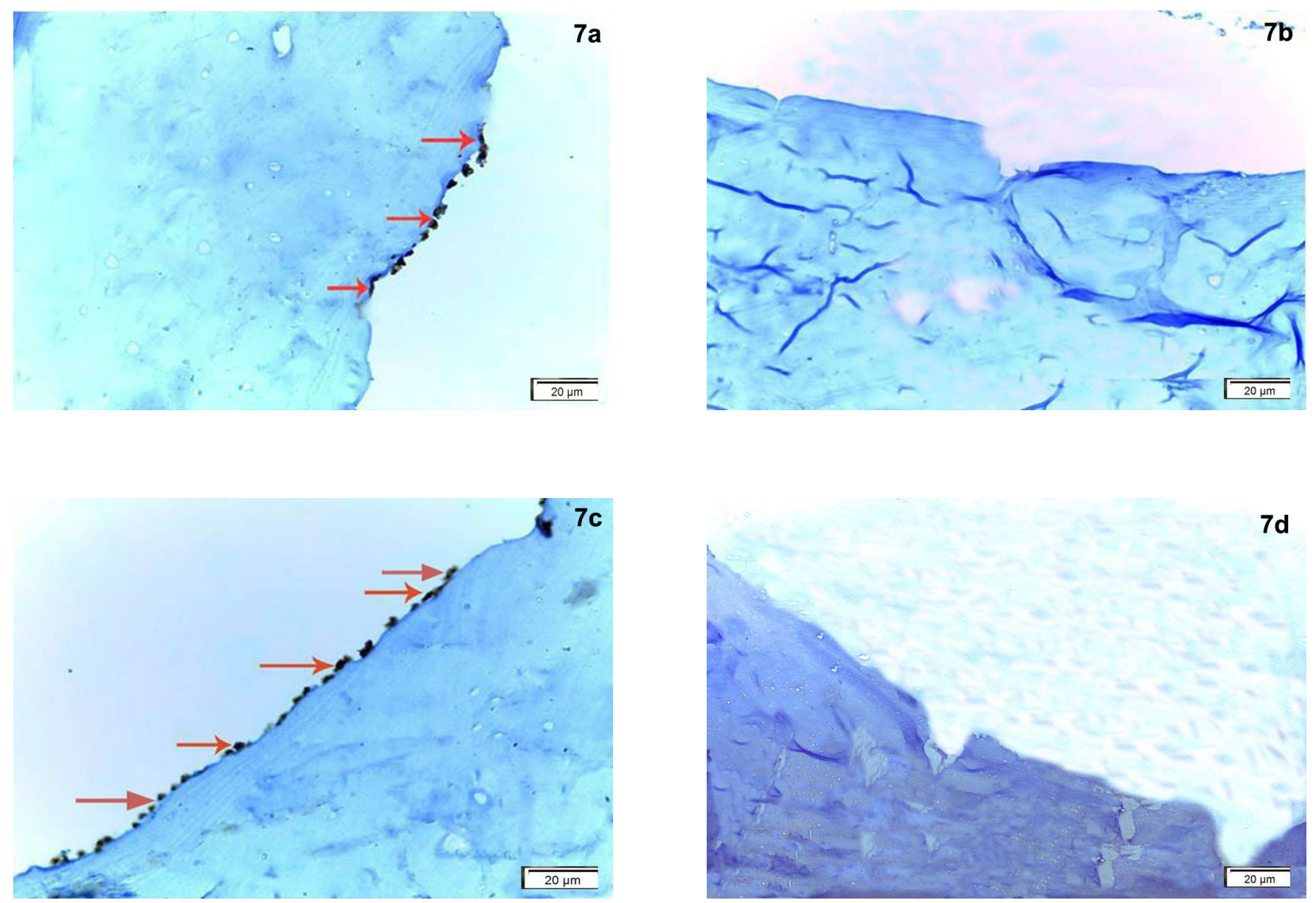

Fig. 7: Photomicrographs of transverse sections from rats' femurs immunostained with anti PCNA antibody (x400). 7a) Group I (control group) presents +ve PCNA immunoreactivity appearing as brown nuclear deposits in the osteoblasts (red arrows). 7b) Group II (OP group) shows -ve PCNA immunoreaction. 7c) Group III (CH group) exhibits numerous +ve PCNA immunostained osteoblasts (red arrow). 7d) Group IV (recovery group) displays -ve PCNA immunoreactivity. 

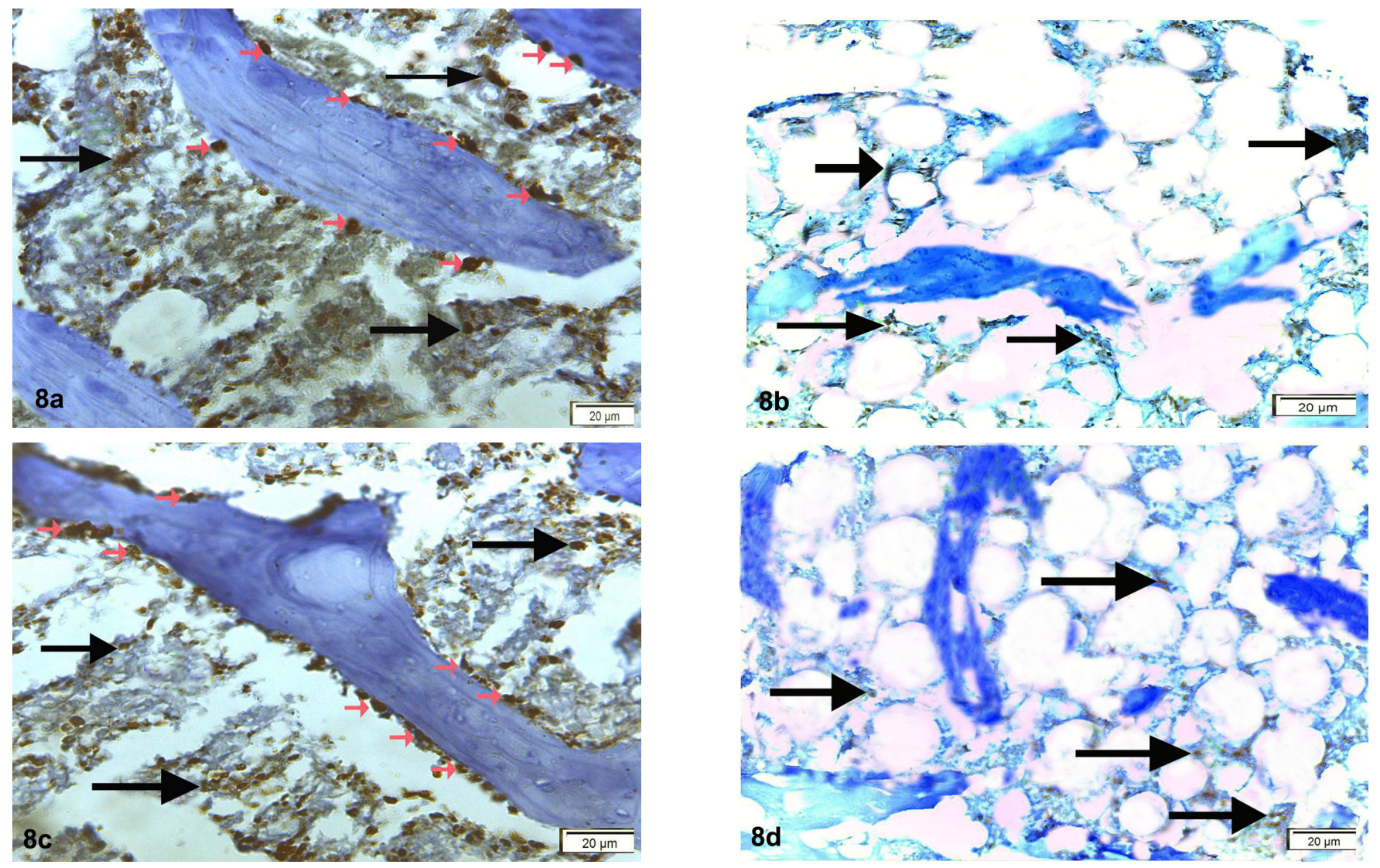

Fig. 8: Photomicrographs of transverse sections from rats' lumbar vertebrae immunostained with anti PCNA antibody (x400). 8a) Group I (control group) shows +ve PCNA immunoreactivity within the nuclei of osteoblasts (red arrows) and most of bone marrow cells (black arrows). 8b) Group II (OP group) displays -ve PCNA immunoreaction, yet, some bone marrow cells show +ve PCNA immunoreactivity (black arrows). 8c) Group III (CH group) presents numerous + ve PCNA osteoblasts (red arrow) and bone marrow cells (black arrows). 8d) Group IV (recovery group) shows -ve PCNA immunoreaction, however, some bone marrow cells are +ve PCNA immunoreactive (black arrows).

Table 1: Mean values $( \pm \mathrm{SD})$ of chemical parameters in the studied groups

\begin{tabular}{lcccc}
\hline Parameters & Group I (Control) & Group II (OP group) & Group III (CH group) & Group IV (Recovery group) \\
\hline Mean serum ALP (U/L) & $122.76 \pm 1.65$ & $307.33 \pm 6.49^{*}$ & $128.91 \pm 1.89^{*}$ & $301.39 \pm 8.16^{*}$ \\
Mean serum ca $^{+2}(\mathrm{mg} / \mathrm{dl})$ & $10.71 \pm 0.12$ & $6.96 \pm 0.96^{*}$ & $10.05 \pm 0.32^{\#}$ & $6.52 \pm 0.88^{*}$ \\
\hline
\end{tabular}

* Significant compared to groups I and III.

\# Significant compared to groups II and IV with no significant difference compared to groups I.

$\$$ Non significant compared to group II.

Table 2: Mean values $( \pm \mathrm{SD})$ of morphometric parameters in the studied groups

\begin{tabular}{lcccc}
\hline Parameters & Group I (Control) & Group II (OP group) & Group III (CH group) & Group IV (Recovery group) \\
\hline Thickness of compact bone $(\mu \mathrm{m})$ & $552.78 \pm 39.82$ & $436.88 \pm 19.11^{*}$ & $548.22 \pm 32.14^{*}$ & $439.39 \pm 13.48^{* \mathrm{~s}}$ \\
Area of trabecular bone $\left(\mathrm{mm}^{2}\right)$ & $2727.8 \pm 194.3$ & $1104.03 \pm 110.8^{*}$ & $2701.9 \pm 214.7^{\sharp}$ & $1109.9 \pm 133.7^{* \mathrm{~s}}$ \\
Area \% of collagen fibers (compact bone) & $94.62 \pm 1.97$ & $29.45 \pm 3.12^{*}$ & $93.51 \pm 2.76^{\sharp}$ & $30.51 \pm 3.05^{* \mathrm{~s}}$ \\
Area \% of collagen fibers (trabecular bone) & $75.70 \pm 4.02$ & $13.93 \pm 1.99^{*}$ & $73.95 \pm 3.87^{\#}$ & $14.69 \pm 2.51^{* \mathrm{~s}}$ \\
Area \% of OPN in compact bone & $23.57 \pm 2.02$ & $0.71 \pm 0.18^{*}$ & $36.59 \pm 2.21^{\alpha}$ & $0.79 \pm 0.16^{*}$ \\
Area \% of OPN in trabecular bone & $11.19 \pm 2.32$ & $0.72 \pm 0.19^{*}$ & $20.09 \pm 2.11^{\alpha}$ & $0.74 \pm 0.14^{* \mathrm{~s}}$ \\
Number of PCNA +ve cells in compact bone & $7.70 \pm 1.33$ & $3.10 \pm 0.57^{*}$ & $17.50 \pm 2.46^{\alpha}$ & $2.40 \pm 0.52^{* \mathrm{~s}}$ \\
Number of PCNA +ve cells in trabecular bone & $11.30 \pm 1.16$ & $2.0 \pm 0.47^{*}$ & $20.10 \pm 1.85^{\alpha}$ & $2.20 \pm 0.42^{* \mathrm{~s}}$ \\
\hline * Significan
\end{tabular}

* Significant compared to groups I and III.

\# Significant compared to groups II and IV with no significant difference compared to groups I.

$\$$ Non significant compared to group II.

$\alpha$ Significant compared to groups I, II and IV. 


\section{DISCUSSION}

In the present study, male albino rats were used to examine the probable protective effect of $\mathrm{CH}$ against fluvoxamine maleate-induced OP; to avoid hormonal changes in female rats like estrogen deficiency that may cause $\mathrm{OP}^{[33]}$. Fluvoxamine maleate $(\mathrm{FM})$ was given for 4 weeks in a non toxic dose of $2 \mathrm{mg} / \mathrm{kg} /$ day; the total effective therapeutic human dose varies from 100 up to $300 \mathrm{mg}^{[34]}$ which is equivalent to about 1.8 to $5.4 \mathrm{mg}$ in rats according to Paget ${ }^{[35]}$, and these dose and duration were proved to be sufficient to induce OP in rats ${ }^{[26]}$. Both compact and trabecular bones were investigated in the current work and due to the multiple similarities between human and rat femur, at the macrostructural and microstructural levels, this site has gained vast importance in OP studies as an example for compact bone ${ }^{[36]}$. In addition, the trabecular bone of the lumbar vertebrae is at higher risk for OP changes and plays a key role in its monitoring ${ }^{[37]}$; therefore it was chosen for histological examination as an example for trabecular bone.

The current work revealed that FM when given alone in both groups II and IV (FM and recovery groups) produced a significant increase in serum alkaline phosphatase (ALP) and a significant decrease in serum calcium $\left(\mathrm{Ca}^{+2}\right)$ compared to the control; which indicates an increase in bone turnover, and this is consistent with several earlier OP studies ${ }^{[21,38,39]}$. This might be explained by that ALP is a cell membrane component of many tissues with the highest concentrations in the liver and bone osteoblasts. So, it is increased in skeletal system diseases as a compensatory reaction to bone destruction $^{[17]}$ due to increased bone turnover ${ }^{[38]}$. Whilst reduced serum $\mathrm{Ca}^{+2}$ in $\mathrm{OP}$ group could be attributed to increased bone resorption causing hypercalcemia, which triggers a compensatory mechanism to reduce its intestinal absorption and increase its renal excretion ${ }^{[40]}$. In group IV (recovery group), these findings was enlightened by previous researchers who stated that FM exerted negative effect on bone metabolism that persisted for a prolonged time after its discontinuation $^{[8]}$.

In the present study, bone sections from both groups II and IV presented the same histological alterations. There were areas of pale stained matrix, indistinct cement lines, decreased bone thickness, thinning and interruption of bone trabeculae, multiple resorption cavities housing many osteoclasts. These findings go on line with former studies ${ }^{[26,41]}$ and were confirmed by morphometric measurements; significant decrease in the mean thickness of compact bone and mean area of trabecular bone compared to control, which is in agreement with other OP studies ${ }^{[42,43,44,45]}$. This might be explained by the disturbance between bone formation and resorption, resulting in remodeling dysregulation with subsequent loss of bone matrix ${ }^{[46]}$. Another explanation could be the increased rate of bone resorption over that of bone formation ${ }^{[47]}$; as regular cement lines mark the edge between old and newly deposited bone and are defined as matrix layers laid down at any time resorption is followed by bone deposition $^{[48]}$. Also, bone sections displayed wide marrow spaces with numerous fat cells and this might be attributed to decreased trabecular bone thickness that leaves more space for the bone marrow ${ }^{[49]}$. Also the shift in differentiation of mesenchymal cells toward adipocytes instead of osteoblastic lineage in bone marrow, results in increased number of fat cells and inactive bone marrow ${ }^{[50]}$.

Moreover, there was irregular eroded endosteal surface with loss of osteoblasts which was reported by previous researchers following the use of SSRIs and they attributed these changes to the decline in osteogenic proliferation and differentiation ${ }^{[48,51]}$. This finding was established immunohistochemically by the significant decrease in OPN and PCNA expression compared to the control, which reflects the activity of osteoblasts, their maturation and the beginning of bone mineralization activity ${ }^{[52,53,54]}$. Low expression of OPN as a bone mineralization marker was formerly reported and it was associated with increased bone fragility and matrix porosity ${ }^{[22,23]}$. Additionally, a decrease in the mean number of PCNA immunostained positive osteoblasts was previously reported with the long term use of SSRIs and FM; as they directly inhibit osteoblasts formation and function and induce their apoptosis ${ }^{[8,51,54,55]}$.

Demineralization of bone following FM was evident in Mallory's trichrome stained sections where bone was formed mostly of immature unmineralized matrix with small areas of mineralization that might be attributed to the decreased number of osteoblasts responsible for bone mineralization ${ }^{[54]}$. This was confirmed morphometrically by the significant decrease in the mean area percent of collagen fibers compared to the control, which is in agreement with previous OP studies ${ }^{[27,54,56]}$.

Moreover, bone sections revealed apoptotic osteocytes and this is consistent with Rochefort ${ }^{[16]}$ who reported osteocytes loss or their presence in few numbers within indistinct lacunae and in irregular orientation as a key feature in the pathogenesis of OP. Besides, whatever the cause of $\mathrm{OP}$, osteocyte cell death occurs resulting in a condition called osteonecrosis or dead bone ${ }^{[57]}$. Moreover, there was apparent widening of osteocytes lacunae in this work that might be explained by the occurrence of osteocytic osteolysis which has a $\mathrm{Ca}^{+2}$ homeostatic effects ${ }^{[58]}$. Consistent with this, previous scientists have found widened osteocytic lacunae in OP rats and other conditions of bone loss ${ }^{[27,59,60]}$. Osteocytic osteolysis is the removal of perilacunar matrix by osteocytes, where they are able to acidify their lacunar-canalicular space through the production of protons via carbonic anhydrase- 2 and the release of protons via proton pumping ATPases. This demineralizes the bone matrix and free calcium, while MMP13, tartrate resistance acid phosphatase and cathepsin $\mathrm{K}$ remove the organic components of the perilacunar matrix ${ }^{[61]}$.

With long term use of SSRIs, the negative effect of peripheral serotonin outweighs the positive central effect ${ }^{[62]}$; as they inhibit osteoblasts differentiation, proliferation and mineralization, decrease matrix proteins formation and lower bone marrow density (BMD), inhibiting bone development ${ }^{[8,54]}$. The effect of SSRIs on bone is governed by activation of 5-HT receptors on osteoblasts ${ }^{[9]}$; binding 
of peripheral serotonin to these receptors triggers 5-HTR1b/PKA/CREB/cyclins signaling cascade, inhibiting cAMP production and phosphorylation mediated by protein kinase A (PKA), thus leads to decreased expression of cyclin genes and decreased osteoblast proliferation ${ }^{[63]}$. Another explanation was given by Gustafsson et al. ${ }^{[64]}$ who reported that SSRIs have increased osteoclastic activity by stimulating receptor activator of nuclear factor kappa-B ligand (RANKL) and inhibiting osteoprotegrin (OPG). RANKL, also known as osteoclast differentiation factor, is produced by osteoblasts and marrow stromal cells. When binds to its RANK receptor on osteoclasts and preosteoclasts, it promotes their proliferation and differentiation ${ }^{[65]}$. OPG is a circulating protein receptor also expressed by osteoblasts and marrow stromal cells. It inhibits osteoclast formation by binding RANKL, thus prevent the stimulatory cell to cell interaction with preosteoclasts and inhibit RANKL/ RANK interactions ${ }^{[6]]}$. Decreasing osteoblasts activity while maintaining osteoclasts function leads to a shift in the bone remodeling balance towards bone resorption and $\operatorname{loss}^{[47]}$. Besides, an in-vitro study provided evidence that SSRIs effect on bone cells is direct in nature rather than serotonindependent ${ }^{[8]}$.

On the other hand, concomitant administration of $\mathrm{CH}$ with FM in group III (CH group) resulted in significant decrease in serum ALP and significant increase in serum $\mathrm{Ca}^{+2}$ compared to both groups II and IV, yet, there was no significant change when compared to the control. This might be explained by that collagen peptides (CP) could reduce bone turnover and promote calcium uptake, thus increase bone formation as was proved previously ${ }^{[21,67,68]}$.

Bone sections from group III ( $\mathrm{CH}$ group) revealed noticeable preservation in the bone microstructure. Osteocytes inside their lacunae were seen in between regular lamellae and the bone matrix appeared deeply eosinophilic with multiple distinct cement lines. The bone trabeculae of lumbar vertebrae appeared thicker and more continuous, with smaller highly cellular marrow cavities compared to OP group. This is in harmony with numerous scientists who documented the protective effect of $\mathrm{CH}$ on bone histology in ovariectomized OP rats ${ }^{[21,37,69]}$. Also $\mathrm{CH}$ intake was found to increase bone mass in growing rats following treadmill training $^{[70]}$ and increase BMD in postmenopausal women with primary age-related $\mathrm{OP}^{[71]}$. Furthermore, in a study done on OP in aged mice, $\mathrm{CH}$ was found to improve the bone architecture in terms of more branching and anastomosing trabeculae and normalizing their integrity ${ }^{[72]}$. Morphometric measurements were supportive to the histological findings; there was significant increase in the mean thickness of compact bone and in the mean area of trabecular bone when compared to FM groups (II and IV). This is in accordance with an earlier study, which investigated the effect of $\mathrm{CH}$ in magnesium deficient OP rats and proved that it could attenuate bone brittleness by increasing cortical thickness ${ }^{[2]}$. Similar finding was reported by Liu et al ${ }^{[21]}$ who stated that CP supplementation could inhibit bone loss with significant increase in the trabecular bone area in ovariectomized OP rats. Adding up, no visible osteoclasts were detected in the present work and this might be accredited to the role of $\mathrm{CH}$ in inhibiting osteoclasts formation and activity ${ }^{[73]}$. Others stated that $\mathrm{CH}$ intake has exerted a significant effect on reducing tartrate-resistant acid phosphatase-5b which is a specific and sensitive biomarker of osteoclasts and its concentration is recognized as a specific index of bone resorption, so $\mathrm{CH}$ plays an important role in reducing bone absorption served by osteoclasts ${ }^{[74]}$.

Moreover, the endosteum was lined with numerous osteoblasts and this was confirmed by significant increase in the mean area percent of OPN and in the mean number of PCNA immunoreactivity in $\mathrm{CH}$ group compared to both osteoporotic groups. In agreement with this, previous researchers have reported that $\mathrm{CP}$ could improve osteoblasts proliferation and differentiation and accelerate matrix mineralization with increased OPN expression ${ }^{[75]}$. They found that when cultured human osteoblasts were treated with $\mathrm{CP}$ for seven days, their number increased significantly compared to untreated cells ${ }^{[76]}$. Furthermore, the effect of $\mathrm{CH}$ on the proliferation of osteoblasts was determined by a colorimetric immunoassay based on quantitating bromodeoxyuridine incorporation into the newly synthesized DNA, and it was found to increase the osteoblastic proliferation ${ }^{[37]}$. The outcome of $\mathrm{CH}$ on bone osteoblasts number, activity and mineralization could be elucidated by the ability of $\mathrm{CH}$ to increase the expression of bone matrix genes that are responsible for bone formation such as ALP, type 1 collagen and OPN. Osteoblasts express OPN and osteocalcin during the mineralization phase. OPN appears prior to osteocalcin and is expressed during the stage of active proliferation. The expression of ALP and OPN accelerates mineralization and leads to increased calcium deposition ${ }^{[77]}$. The increased expression of OPN and osteocalcin was proved by different studies following $\mathrm{CH}$ treatment associated with prevention of apoptosis ${ }^{[72,78,79]}$.

Adding up, Mallory's trichrome stained sections showed that bone was formed mostly of mineralized matrix with significant increase in the mean area percent of collagen fibers compared to FM groups. This is consistent with former studies that compared $\mathrm{CH}$ treated rats to ovariectomized OP rats $^{[27]}$, and could be elucidated by the increased number of osteoblasts and enhancement in their activity that results in increased bone mineralization and synthesis of organic bone matrix components ${ }^{[68,78,80]}$. Also, a CH-enriched diet was found to improve bone collagen metabolism and $\mathrm{BMD}^{[20]}$. Adding up, Kim et al. ${ }^{[37]}$ supported this point by demonstrating the effects of $\mathrm{CH}$ in-vitro and in-vivo. In the in-vitro tests; it was observed that $\mathrm{CH}$ has increased osteoblasts proliferation and ALP activity, increased bone matrix proteoglycans and improved bone collagen metabolism, collagen synthesis and collagen typel alphal gene expression. In the-vivo tests; they found significant increase in BMD in the lumbar vertebrae. Increased osteoblasts activity is due to interaction between type I collagen and alpha 2 , beta 1 integrin receptors on osteoblasts cell membranes which induces their differentiation leading to increased ALP 
activity and expression of bone matrix proteins such as type I procollagen, OPN and matrix Gla protein. Moreover, $\mathrm{CH}$ intake was found to significantly increase the level of alpha 2, beta 1 integrin receptors ${ }^{[72]}$. Increasing BMD could be assigned to the composition of bone; as it is made of approximately $70 \%$ inorganic salts (minerals) and 30\% organic matrix, with collagen accounting for over $90 \%$ in this organic part. Minerals play a significant role in bone mass but without enough collagen, taking large amount of minerals is wasteful, as there is inadequate framework for minerals to attach to. Hence, collagen provides a framework where calcium adheres on, creating a hardened soft tissue framework $^{[71,81]}$.

\section{CONCLUSION}

Data from this study provide evidence that Fluvoxamine maleate (a common SSRI) leads to osteoporosis affecting both compact and trabecular bones. Also this work proved that concomitant administration of collagen hydrolysate could protect the bone tissue by enhancing osteoblasts proliferation and mineralization. Therefore, it is advisable to use $\mathrm{CH}$ for patients assigned to SSRIs therapy, during the course of treatment; to prevent bone loss and reduce the incidence of osteoporosis.

\section{CONFLICTS OF INTEREST}

There are no conflics of interest.

\section{REFERENCES}

1. Wadhwa R, Kumar M, Talegaonkar S and Vohora D. Serotonin reuptake inhibitors and bone health: a review of clinical studies. Osteoporosis and sarcopenias. 2017; 3(2): 75-81.

2. Noma T, Takasugi S, Shioyama M, Yamaji T, Itou H, Suzuki Y, Sakuraba K and Sawaki K. Effects of dietary gelatin hydrolysates on bone mineral density in magnesiumdeficient rats. BMC Musculoskeletal Disorders. 2017; 18(1): pp.385-390.

3. Heng Y, Shanfu W, Yafeng Z, Mao W, Jianwei $\mathrm{W}$ and Yong $\mathrm{M}$. Zuogui pill improves the dexamethasone-induced osteoporosis progression in zebrafish larvae. Biomedicine \& Pharmaotherapy, 2018; 97: 995-999.

4. Chen F, Hahn TJ and Weintraub NT. Do SSRIs play a role in decreasing bone mineral Density. JAMDA. 2012; 13(5): 413-417.

5. Erdemir F, Atilgan D, Firat F, Markoc F, Parlaktas BS and Sogut E. The effect of sertraline, paroxetine, fluoxetine and escitalopram on testicular tissue and oxidative stress parameters in rats. Int. braz $\mathrm{j}$ urol. 2014; 40(1): 100-108.

6. Schweiger JU, Schweiger U, Hüppe M, Kahl KG, Greggersen W, Jauch-Chara K and Fassbinder E. The use of antidepressive agents and bone mineral density in women: a meta-analysis. Int J Environ Res Public Health. 2018; 15(7): 1373-1383.
7. Wu X, Al-Abedalla K, Rastikerdar E, Nader SA, Daniel NG, Nicolau B and Tamimi F. Selective serotonin reuptake inhibitors and the risk of osseointegrated implant failure: a cohort study. J Dent Res. 2014; 93(11): 1054-1061.

8. Bradaschia-Correa V, Josephson AM, Mehta D, Mizrahi M, Neibart SS, Liu C, Kennedy OD, Castillo AB, Egol KA and Leucht P. The selective serotonin reuptake inhibitor fluoxetine directly inhibits osteoblast differentiation and mineralization during fracture healing in mice. Journal of Bone and Mineral Research. 2017; 32(4): 821-833.

9. Tsapakis EM, Gamie Z, Tran GT, Adshead S , Lampard A, Mantalaris A and Tsiridis E. The adverse skeletal effects of selective serotonin reuptake inhibitors. Europian Psychiatry. 2012; 27(3): 156-169.

10. Galal AA, Alam RT and Abd El-Aziz RM. Adverse effects of long-term administration of fluvoxamine on haematology, blood biochemistry and fertility in male albino rats: a possible effect of cessation. Andrologia. 2016; 48(9): 1002-1010.

11. Katsuki A, Fujino Y, Nguyen HL and Yoshimura R. Do benzodiazepines plus fluvoxamine cause a rapid increase in serum brain-derived neurotrophic factor or clinical improvement in major depressive disorder patients? Neuropsychiatry (London). 2018; 8(1): 18-23.

12. Hashimoto K. Activation of sigma-1 receptor chaperone in the treatment of neuropsychiatric diseases and its clinical implication. Journal of Pharmacological Sciences. 2015; 127(1): 6-9.

13. Bandelow B, Lichte $\mathrm{T}$, Rudolf S, Wiltink $\mathrm{J}$ and Beutel ME. The german guidelines for the treatment of anxiety disorders. Eur Arch Psychiatry Clin Neurosci. 2015; 265(5): 363-373.

14. Skapinakis P, Caldwell DM, Hollingworth W, Bryden P, Fineberg NA, Salkovskis P, Welton NJ, Baxter H, Kessler D, Churchill R and Lewis G. Pharmacological and psychotherapeutic interventions for management of obsessivecompulsive disorder in adults: a systematic review and network meta-analysis. The Lancet Psychiatry. 2016; 3(8): 730-739.

15. Yue JK, Burke JF, Upadhyayula PS, Winkler EA, Deng H, Robinson CK, Pirracchio R, Suen CG, Sharma S, Ferguson AR, Ngwenya MB, Stein LB, Manley GT and Tarapore PE. Selective serotonin reuptake inhibitors for treating neurocognitive and neuropsychiatric disorders following traumatic brain injury: an evaluation of current evidence. Brain Sci. 2017; 7(8): 93-108. 
16. Rochefort GY. The osteocyte as a therapeutic target in the treatment of osteoporosis. Ther Adv Musculoskelet Dis. 2014; 6(3):79-91.

17. Porfírio E and Fanaro GB. Collagen supplementation as a complementary therapy for the prevention and treatment of osteoporosis and osteoarthritis: a systematic review. Rev Bras Geriatr Gerontol. 2016; 19(1): 153-164.

18. Yazaki M, Ito Y, Yamada M, Goulas S, Teramoto $\mathrm{S}$, Nakaya Ma, Ohno Sh and Yamaguchi $\mathrm{K}$. Oral ingestion of collagen hydrolysate leads to the transportation of highly concentrated gly-pro-hyp and its hydrolyzed form of prohyp into the bloodstream and skin. J Agric Food Chem. 2017; 65(11): 2315-2322.

19. Sibilla S, Godfrey M, Brewer S, Budh-Raja A and Genovese L. An overview of the beneficial effects of hydrolysed collagen as a nutraceutical on skin properties: scientific background and clinical studies. The Open Nutraceuticals Journal. 2015; 8: 29-42.

20. De Almeida Jackix E, Cúneo F, Amaya-Farfan J, Assunção JV and Quintaes KD. A food supplement of hydrolyzed collagen improves compositional and biodynamic characteristics of vertebrae in ovariectomized rats. Journal of Medicinal Food. 2010; 13(6):1385-1390.

21. Liu J, Wang Y, Song S, Wang X, Qin Y, Si S and Guo Y. Combined oral administration of bovine collagen peptides with calcium citrate inhibits bone loss in ovariectomized rats. PLoS One. 2015; 10(8): e0135019.

22. Altowity SA, Abdel-Rahman AH, Kasem RF and Elsebaie MM. Role of mesenchymal stem cells in bone healing of rat bisphosphonate-induced osteonecrosis of the jaw. Journal of Medical Sciences. 2018; 18(2): 87-95.

23. Yogui FC, Momesso GA, Faverani LP, Polo TO, Ramalho - Ferreira G, Hassumi JS, Rossi AC, Freire AR, Prado FB and Okamoto R. A SERM increasing the expression of the osteoblastogenesis and mineralization-related proteins and improving quality of bone tissue in an experimental model of osteoporosis. J Appl Oral Sci. 2018; 26: e20170329.

24. Bei J, Zhang X, Wu J, Hu Z, Xu B, Lin S, Cui $\mathrm{L}, \mathrm{Wu} \mathrm{T}$ and $\mathrm{Zou} \mathrm{L}$. Ginsenoside Rb1 does not halt osteoporotic bone loss in ovariectomized rats. PLoS One. 2018; 13(9): e0202885.

25. Koley S, Chakrabarti S, Pathak S, Manna AK and Basu S. Cytological study of breast carcinoma before and after oncotherapy with special reference to morphometry and proliferative activity. Indian Journal of Surgery. 2015; 77(2): 570-575.
26. Afifi OK. Histological study on the effect of fluvoxamine maleate on the femur of adult male albino rat. Egyptian Journal of Histology. 2010; 33(2): 270-278.

27. Abd El Moneim RA and Mahmoud SA. Histological study of the femur and the lumbar vertebrae in ovariectomized adult albino rats following administration of collagen hydrosylate. Egyptian Journal of Histology. 2013; 36(3): 646-659.

28. Pourghasem M, Nasiri E and Shafi H. Early renal histological changes in alloxan-induced diabetic rats. Int J Mol Cell Med. 2014; 3(1): 11-15.

29. Bancroft JD and Gamble MN. Theory and practice of histological techniques. $6^{\text {th }}$ ed. London, Edinburg, New York, Philadelphia, St Louis, Sydney and Toronto: Churchill-Livingstone. 2007; pp. 179.

30. Kiernan JA. Histological and histochemical methods: theory and practice. 5th edition, Scion Publishing, Banbury. 2015; pp. 111-162.

31. Suvarna K, Layton C and Bancroft J. Bancroft's theory and practice of histological techniques $7^{\text {th }} \mathrm{Ed}$, Elsevier Health Sciences, China. 2012; pp.493-538.

32. Emsley R, Dunn G, White IR. Mediation and moderation of treatment effects in randomised controlled trials of complex interventions. Stat Methods Med Res. 2010; 19: 237-270.

33. Gallagher JC and Tella SH. Prevention and treatment of postmenopausal osteoporosis. J Steroid Biochem Mol Biol. 2014; 142: 155-170.

34. Morishita S and Arita S. Suitable dose and duration of fluvoxamine administration to treat depression. Psychiatry and Clinical Neurosciences. 2003; 57: 177-181.

35. Paget GE and Barnes JM. Toxicty test in: Laurnce DR, Bacharach AL, editors. Evaluation of drug activities: pharmacometrics. Academic press, London and New York, 1964; volume 1, pp: 135.

36. Tezval M, Serferaz G, Rack T, Kollos L, Sehmisch S, Schmelz U, Tezval H, Stuermer KM and Stuermer EK. Effect of parathyroid hormone on hypogonadism induced bone loss of proximal femur of orchiectomized rat. World J Urol. 2011; 29(4): 529-534.

37. Kim HK, Kim MG and Leem KH. Osteogenic activity of collagen peptide via ERK/MAPK pathway mediated boosting of collagen synthesis and its therapeutic efficacy in osteoporotic bone by backscattered electron imaging and microarchitecture analysis. Molecules. 2013; 18(12): 15474-15489.

38. Faldu KG, Duvva H, Shah JS, Shah PV and Patel SS. An ayurvedic proprietary herbal preparation, calci-7, prevents ovariectomy-induced osteoporosis in rats. Ayu J. 2016; 3793(4): 250-255. 
39. Hozayen WG, El-Desouky MA, Soliman HA, Ahmed RR and Khaliefa AK. Antiosteoporotic effect of petroselinum crispum, ocimum basilicum and cichorium intybus 1 . in glucocorticoid-induced osteoporosis in rats. BMC Complementary and Alternative Medicine. 2016; 16: 165-176.

40. Grigoryan AV, Dimitrova AA, Kostov KG, Russeva AL, Atanasova MA, Blagev AB, Betova TM and Trifono RG. Changes of serum concentrations of alkaline phosphatase and metalloproteinase- 9 in an ovariectomized wistar rat model of osteoporosis .J Biomed Clin Res. 2017; 10(1): 32-36.

41. Shata A, Firgany AE and Abdel-Hamid AA. Ameliorating effect of combination of simvastatin and residronate on glucocorticoid induced osteoporosis model in rats.Afr. J. Pharm. Pharmacol. 2015; 9(28): 701-710.

42. Sharaf HA, Shaffie NM, Morsy FA, Badawi MA and Abbas NF. Role of some phytoestrogens in recovering bone loss: histological results from experimental ovariectomized rat models. Journal of the Arab Society for Medical Research. 2015; 10(2): 65-75.

43. Sun $\mathrm{D}$, Zheng $\mathrm{X}$, Chen $\mathrm{Y}$, Jia $\mathrm{C}, \mathrm{Xu} \mathrm{S}$, Lin C, Zhang $\mathrm{P}$, Zhang Z, Cai D, Jin D, Zhang $\mathrm{B}$ and Bai X. Enhancement of osteogenesis post-splenectomy does not attenuate bone loss in ovariectomized rats. Journal of orthopaedic research. 2015; 33(9): 1356-1363.

44. Farag AI, Ahmad MM and Hassanein GH. Effect of carbonated soft drinks consumption on the bone of wistar albino rat: a histomorphometric study. J Am Sci. 2016; 12(8): 78-84.

45. Kumar M, Wadhwa R, Kothari P, Trivedi R and Vohora D. Differential effects of serotonin reuptake inhibitors fluoxetine and escitalopram on bone markers and microarchitecture in wistar rats. Eur J Pharmacol. 2018; 825: 57-62.

46. Erben RG. Hypothesis: Coupling between resorption and formation in cancellous bone remodeling is a mechanically controlled event. Front Endocrinol (Lausanne). 2015; 6: 82-86.

47. Siegenthaler B, Ghayor C, Gjoksi-Cosandey B, Ruangsawasdi $\mathrm{N}$ and Weber FE. The Bromodomain inhibitor n-methyl pyrrolidone prevents osteoporosis and bmp-triggered sclerostin expression in osteocytes. Int J Mol Sci. 2018; 19(11): 3332-3345.

48. Török-Oance $\mathrm{R}$ and Vasile L. Aspects of bone tissue in osteoporosis. Annals of west university of timişoara, ser. Biology. 2014; 17 (2): 129-136.

49. Lorentzon M and Cummings SR. Osteoporosis: the evolution of a diagnosis. Journal of Internal Medicine. 2015; 277(6): 650-661.
50. Tencerova $\mathrm{M}$ and Kassem M. The bone marrowderived stromal cells: commitment and regulation of adipogenesis. Front Endocrinol. 2016; 7:127-138

51. Rauma PH, Honkanen RJ,Williams LJ, Tuppurainen MT, Kröger HP and Koivumaa-Honkanen H. Effects of antidepressants on postmenopausal bone loss-A 5-year longitudinal study from the OSTPRE cohort. Bone. 2016; 89: 25-31.

52. Oliveira D, Hassumi JS, Gomes-Ferreira PH, Polo TO, Ferreira GR, Faverani LP and Okamoto R. Short term sodium alendronate administration improves the peri-implant bone quality in osteoporotic animals. J Appl Oral Sci. 2017; 25(1): 42-52.

53. Wang F, Zhao Y, Liu Y, Yu P, Yu Z Wang J and Xue C. Peptides from Antarctic krill (Euphausia superba) ameliorate senile osteoporosis via activating osteogenesis relatedBMP2/Smads and Wnt/b-catenin pathway. J Food Biochem. 2017; 41(4): 212381

54. Nam SS, Lee JC, Kim HJ, Park JW, Lee JM, Suh, JY, Um HS, Kim JY, Lee Y and Kim YG. Serotonin inhibits osteoblast differentiation and bone regeneration in rats. Journal of Periodontology. 2016; 87(4): 461-469.

55. Kristjansdottir HL, Lewerin C, Lerner UH, Waern E, Johansson H, Sundh D, Karlsson M, Cummings SR, Zetterberg H, Lorentzon M, Ohlsson C and Mellstrom D. High serum serotonin predicts increased risk for hip fracture and nonvertebral osteoporotic fractures: the MrOS sweden study. Journal of Bone and Mineral Research. 2018; 33(9): 1560-1567.

56. Cignachi NP, Pesquero JB, Oliveira RB, Etges $\mathrm{A}$ and Campos MM. Kinin b1 receptor deletion affects bone healing in type 1 diabetic mice. Journal of Cellular Physiology. 2015; 230(12): 3019-3028.

57. Bonewald LF. The role of the osteocyte in bone and non bone disease. Endocrinol Metab Clin North Am. 2017; 46(1):1-18.

58. Alliston T. Biological regulation of bone quality. Curr Osteoporos Rep. 2014; 12(3): 366-375.

59. Clarke MV, Russell PK, Findlay DM, Sastra S, Anderson PH, Skinner JP, Atkins GJ, Zajac JD and Davey RA. A role for the calcitonin receptor to limit bone loss during lactation in female mice by inhibiting osteocytic osteolysis. Endocrinology. 2015; 156(9): 3203-3214.

60. Sun B, Sun J, Han X, Liu H, Li J, Du J, Feng W, Liu B, Cui J, Guo J, Amizuka N and Li M. Immunolocalization of MMP 2, 9 and 13 in prednisolone induced osteoporosis in mice. Histol Histopathol. 2016; 31(6): 647-656. 
61. Tsourdi E, Jähn K, Rauner M, Busse B and Bonewald LF. Physiological and pathological osteocytic osteolysis. J Musculoskelet Neuronal Interact. 2018; 18(3): 292-303.

62. Ducy P and Karsenty G. The two faces of serotonin in bone biology. The Journal of cell biology. 2010; 191(1): 7-13.

63. Michalowska M, Znorko B, Kaminski T, Oksztulska-Kolanek E and Pawlak D. New insights into tryptophan and its metabolites in the regulation of bone metabolism. Journal of Physiology and Pharmacology. 2015; 66(6): 779-791.

64. Gustafsson B, Thommesen L, Stunes AK, Tommeras K, Westbroek I, Waldum H, Slørdahl K, Tamburstuen MV, Reseland JE and Syversen U. Serotonin and fluoxetine modulate bone cell function in vitro. Journal of cellular biochemistry. 2006; 98(1): 139-151.

65. Liu $\mathrm{W}$ and Zhang X. Receptor activator of nuclear factor $\kappa B$ ligand (RANKL)/ RANK/osteoprotegerin system in bone and other tissues (review). Molecular Medicine Reports. 2015; 11(5): 3212-3218.

66. Hienz SA, Paliwal S and Ivanovski S. Mechanisms of bone resorption in periodontitis. J Immunol Res. 2015; 2015: 615486.

67. Hou T, Liu Y, Guo D, Li B and He H. Collagen peptides from crucian skin improve calcium bioavailability and structural characterization by HPLC-ESI-MS/MS. J Agric Food Chem. 2017; 65(40): 8847-8854.

68. Li Y, Zhao Y, Sun X and Qu X. Prevention and therapeutic effects of sika deer velvet collagen hydrolysate on osteoporosis in rats by retinoic acid. Zhongguo Zhong Yao Za Zhi. 2010; 35(6): 759-762.

69. Guillerminet F, Fabien-Soulé V, Even PC, Tomé D, Benhamou CL, Roux C and Blais A. Hydrolyzed collagen improves bone status and prevents bone loss in ovariectomized $\mathrm{C} 3 \mathrm{H} / \mathrm{HeN}$ mice. Osteoporos Int. 2012; 23(7):1909-1919.

70. Takeda S, Park JH, Kawashima E, Ezawa I and Omi N. Hydrolyzed collagen intake increases bone mass of growing rats trained with running exercise. J Int Soc Sports Nutr. 2013; 10(1): 35-43.

71. König D, Oesser S, Scharla S, Zdzieblik D and Gollhofer A. Specific collagen peptides improve bone mineral density and bone markers in postmenopausal women - a randomized controlled study. Nutrients. 2018; 10(97): 97-107.
72. Zhang L, Zhang S, Song $\mathrm{H}$ and Li B. Effect of collagen hydrolysates from silver carp skin (hypophthalmichthys molitrix) on osteoporosis in chronologically aged mice: increasing bone remodeling. Nutrients. 2018; 10(10): 1434-1446.

73. Uehara K, Takahashi A, Watanabe M and Nomura Y. Shark protein improves bone mineral density in ovariectomized rats and inhibits osteoclast differentiation. Nutrition. 2014; 30(6): 719-725.

74. Song H, Zhang S, Zhang L and Li B. Ingestion of collagen peptides prevents bone loss and improves bone microarchitecture in chronologically aged mice. Journal of Functional Food. 2019; 52: 1-7.

75. Yamada S, Yoshizawa Y, Kawakubo A, Ikeda T, Yanagiguchi K and Hayashi Y. Early gene and protein expression associated with osteoblast differentiation in response to fish collagen peptides powder. Dental Materials Journal. 2013; 32(2): 233-240.

76. Liu J, Zhang B, Song S, Ma M, Si SY, Wang Y, $\mathrm{Xu} \mathrm{B}$, Feng $\mathrm{K}, \mathrm{Wu} \mathrm{J}$ and Guo Y. Bovine collagen peptides compounds promote the proliferation and differentiation of MC3T3-E1 preosteoblasts. PLoS One. 2014; 9(6): e99920.

77. Kim HK, Kim MG and Leem KH. Collagen hydrolysates increased osteogenic gene expressions via MAPK signaling pathway in MG-63 human osteoblasts. Food Funct. 2014; 5(3): 573-578.

78. Daneault A, Prawitt J, Soulé VF, Coxam V and Wittrant Y. Biological effect of hydrolyzed collagen on bone metabolism. Critical Reviews in Food Science and Nutrition. 2017; 57(9): 1922-1937.

79. $\mathrm{Lu} \mathrm{M}$ and Zhao XH. The growth proliferation, apoptotic prevention and differentiation induction of the gelatinhydrolysates from three sources to human fetalosteoblasts (hFOB 1.19 Cells). Molecules. 2018; 23(6): 1287-1304.

80. Guillerminet F, Beaupied H, Fabien-SouléV, Tomé D, Benhamou CL, Roux C and Blais A. Hydrolyzed collagen improves bone metabolism sand biomechanical parameters in ovariectomized mice: An in vitro and in vivo study. Bone. 2010; 46(3): 827-834.

81. Zhang H, Dong Y, Qi B, Liu L, Zhou G, Bai X, Yang C, Zhao D and Zhao Y. Preventive effects of collagen peptide from deer sinew on bone loss in ovariectomized rats. Evid Based Complement Altern Med. 2014; 2014: ID 627285-9 pages. 
الملخص العربى هيدروليسات الكولاجين ضد ترقق العظام المحدث بماليات القلوفوكسامين في الجرذان

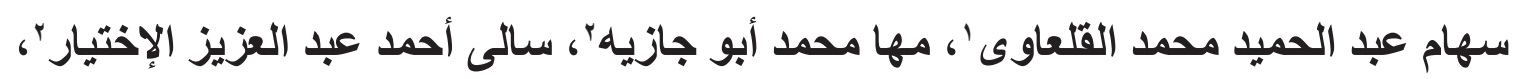

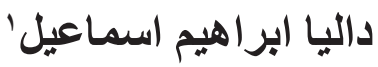

\section{أقسم الهيستولوجيا، كلية الطب، جامعة القاهرة

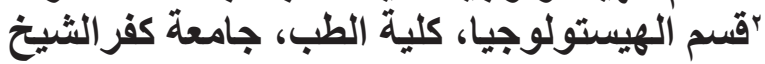

الخلقية: ترقق العظام هو مرض عظام تتكسى سائد بين المرضى الذين يتلقون مثبطات امتصاص السيروتونين الانتقائية منل ماليات الفلوفوكسامين. و هيدروليسات الكو لاجين مكون غذائي له نأثير مضاد للارتشاف. الهدف من العمل: تقييم التأثير الوقائي المحتمل لهيدروليسات الكو لاجين ضد ترقق العظام المحدث بماليات الفلوفوكسامين فى ذكور الجرذان البيضاء البالغين. المواد والطرق: تم تقسيم ست وثلاثون جرذاً إلى أربعة مجموعات ، المجموعة الأولى (المجموعة الضابطة) ،

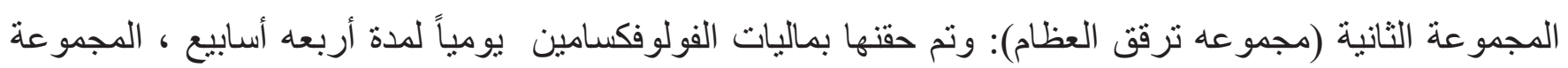
الثالثة (مجمو عة هيدروليسات الكو لاجين): تلقت ماليات الفلوفوكسامين بالإضافة الي هيدروليسات الكو لاجين بالفم لمدة أربعة أسابيع ، المجموعة الر ابعة (مجموعة التعافى): تلقت ماليات الفولوفوكسامين فقط لمدة أربعة أسابيع ثم تركت بدون إعطاء أى أدويه لمدة أربعه أسابيع أخرى. تم قياس نسبة الفوسفاتيز القلوي و الكالسيوم فى مصل الدم. ونم تحضير عينات العظم من عظمة الفخذ اليمنى وعظمة الفقرة القطنية الأولى وصباغتها بصبغة الهيماتوكسيلين و الإيوسين ، لهون صبغة مالوري ثلاثي الألو ان ، صبغات هستو كيميائية مناعية ضد البروتين العظمى الجسرى وضد مولد المضاد النووى للخلايا المتكاثرة. - و تنا ذلك تحليل قياسى و إحصائي. النتائج: أظهرت المجموعنان الثانية و الرابعة ارتفاعًا ذا دلالة إحصائية في الفوسفاتيز القلوي وانخفاضًا ذا دلالة إحصائية في الكالسيوم مقارنةً بالمجمو عة الضابطة. أظهر فحص قطاعات العظم وجود تغير ات هستولوجية و اضحة ؛ ظهرت الخلايا العظمية بنو ايا صغيرة وداكنة فى داخل ثغر ات و اسعة مع وجود اتساع فى قنو ات هافرسى. كما أظهر قالب العظم أماكن ضعيفة الصبغة ، تجاويف عديدة ، كما وجد تجاويف منآكلة بداخلها خلاياعظمية آكلة. كما وجد إنخفاضاً ذو دلالة إحصائية فى متوسط سمك العظم المحكم ، متوسط مساحة العظم الحويجزي ، متوسط النسبة المئوية للتفاعل المناعي بالبروتين العظمى الجسرى ، ومتوسط عدد الخلايا المتفاعلة مناعياً مع مولا المضاد النووى للخلايا مقارنةً بالمجموعة الضابطة. و أظهرت المجموعة الثالثة منوسط إنخفاضاً ذا دلالة دلالة إحصائية في الفوسفاتيز القلوي 
وارتفاعًا ذا دلالة إحصائية في الكالسيوم. أظهر العظم حفاظاً أكثر على البنية الهستولوجية. كما وجد إرتفاعاً ذا دلالة إحصائية فى متوسط سمك العظم المحكم ، متوسط مساحة سطح العظم الحويجزى ، متوسط النسبة المئوية للتفاعل المناعي بالبروتين العظمى الجسرى ، ومتوسط عدد الخلايا المتفاعلة مناعياً مع مولد المضاد النووى للخلايا مقارنةً بالمجمو عتين الثانية و الر ابعة. الإستتتاج: هيدروليسات الكو لاجين له نأثير قوى فى حماية العظم من ترقق العظام المحدث بماليات الفلوفوكسامين. 